\title{
A Survey of Mycorrhizal Colonization in the 50-ha Korup Forest Dynamic Plot in Cameroon
}

\author{
Eneke Esoeyang Tambe Bechem*, George Bindeh Chuyong, Belinda Tengu Fon \\ Department of Botany and Plant Physiology, University of Buea, Buea, Cameroon \\ Email: tamenekeso@yahoo.co.uk
}

Received 9 January 2014; revised 18 March 2014; accepted 9 April 2014

Copyright (C) 2014 by authors and Scientific Research Publishing Inc.

This work is licensed under the Creative Commons Attribution International License (CC BY). http://creativecommons.org/licenses/by/4.0/

c) (i) Open Access

\begin{abstract}
A study was carried out in the 50-ha Korup Forest Dynamic Plot in South West Cameroon, to evaluate the diversity of mycorrhizal associations as well as to determine the effect of habitat types on the type of mycorrhizal association. A total of 781 individual trees belonging to 51 families, 165 genera and 252 tree species, were sampled from the four habitat types found in the plot: low drier, hill slope, ridge top and wetland complexes. In each habitat type, all stems $\leq 1 \mathrm{~cm}$ depth at breast height had already been tagged, measured, mapped and identified to the species level. Root samples were collected, cleared, stained and examined microscopically for mycorrhizal type. Of the total number of species sampled, $248(98.41 \%)$ formed mycorrhizal associations with only 4 $(1.59 \%)$ being non mycorrhizal. For mycorrhizal trees, $232(93.55 \%)$ formed exclusively arbuscular mycorrhiza, $10(4.03 \%)$ formed ectomycorrhiza, while $6(2.42 \%)$ formed both ecto- and arbuscular mycorrhiza. The ridge top harbored the least number (152) of mycorrhizal trees while the low drier area harbored the most number (266) of mycorrhizal trees. Although habitat effect was not significant in influencing mycorrhizal colonization of tree species, some tree species did show aggregated patterns in particular habitats.
\end{abstract}

\section{Keywords}

Korup Forest Dynamic Plot, Arbuscular Mycorrhiza, Ectomycorrhiza, Cameroon

\section{Introduction}

Some of the most important functions of terrestrial ecosystems as well as interactions between plants take place

Corresponding author

How to cite this paper: Bechem, E.E.T., et al. (2014) A Survey of Mycorrhizal Colonization in the 50-ha Korup Forest Dynamic Plot in Cameroon. American Journal of Plant Sciences, 5, 1403-1415. http://dx.doi.org/10.4236/ajps.2014.510155 
below ground and mycorrhizal fungi play important roles in soil ecology.

Mycorrhizal associations which were previously thought to be limited to temperate zones have been shown to occur in natural tropical forests [1]-[7].

Mycorrhizal fungi are known to play important roles in the mineral nutrition and water uptake of plants, protection against diseases etc. [8]. They give plants access to otherwise unavailable mineral sources. In spite of these important roles that mycorrhizal fungi play in plant growth and development, ecological data on the distribution and abundance of colonization especially in tropical ecosystems, are scarce. Information on the role played by mycorrhizal fungi in nutrient cycling in tropical ecosystems is also sketchy.

The study carried out by [5] was a survey of mycorrhizal infection in an Amazonian rain forest while [3] reviewed mycorrhizas in tropical rain forests. Reference [9] evaluated mycorrhizal associations in the rain forests of South Cameroon. Reference [1] looked at the mycorrhizal status of Gnetum spp. in Cameroon. No study has been reported so far on the type of mycorrhizas found in the 50-ha Korup Forest Dynamic Plot (KFDP). Research on mycorrhizas in African tropical forests is expected to help demonstrate their role in the maintenance of high biodiversity and productivity of these forests.

For there to be any meaningful conclusions as to the role of mycorrhizal fungi in biodiversity and productivity in the tropics, there must be a proper inventory on the type of mycorrhizas formed in as many of such systems as possible. This information can then be related to nutrient cycling studies before proper conclusions are drawn.

The 50-Hectare Korup Forest Dynamics Plot (KFDP) which was established in 1996, is an area mapped out within the Korup National Park (KNP), located in the Guineo-Congolian forest in the southwestern part of Cameroon. A detailed description of this plot is given in [10] and [11]. The main objective that led to the establishment of the KFDP was to enable the cataloging, studying and conservation of the extensive biodiversity of Cameroon [10].

A detailed topographic survey of the plot has been carried out and the plot is divided into 1250 quadrats and subquadrats. All trees with a diameter at breast height (dbh) of over $1 \mathrm{~cm}$ have been enumerated and each tree identified using standard methods with most herbarium vouchers held at the Limbe Botanic Garden herbarium, National Herbarium in Yaoundé and Missouri Botanic Garden herbarium. Maps have been produced showing the distribution of each species within the 50-ha plot [10]. The results on the plant diversity study carried out on this plot as reported in [10] and [12] go to confirm the richness in plant species diversity in the tropical rain forest of Cameroon.

In order to clearly understand how tropical forests maintain such high levels of species diversity, it would be necessary to evaluate below ground diversity of the KFDP, of which mycorrhiza associations are the most important.

An understanding of mycorrhizal diversity in the forest soil and the integration of such information into already existing data (plant enumeration and forest composition) would therefore help in explaining the role of interactions in ecosystem functioning and dynamics.

The overall objective of this study was therefore to examine the mycorrhizal status of the tree species in the 50-ha KFDP in Korup National Park. The observations would be compared to the nutrient cycling and other relevant data that already exist on this study site, with the hope of improving on the understanding of ecosystem processes.

In the course of the investigation, an attempt was made to answer the following questions; 1) Which mycorrhiza association was more prevalent in the KFDP? 2) Are arbuscular mycorrhizas more abundant as compared to ectomycorrhizas? 3) Are ectomycorrhiza tree species restricted to particular microhabitats? 4) How does mycorrhiza type influence species coexistence and diversity?

\section{Materials and Methods}

This study was carried out in the year 2010 .

\subsection{Site Description}

The KNP is located between $4^{\circ} 54^{\prime}$ to $5^{\circ} 28^{\prime} \mathrm{N}$ latitude and $8^{\circ} 42^{\prime}$ to $9^{\circ} 16^{\prime} \mathrm{E}$ longitude and is in the Lower Guinean section of the Guineo-Congolian forest which is the second largest block (127,000 ha) of the tropical rain forest. The 50-ha KFDP is located around the southern end of the KNP in Mundemba, Cameroon. The plot has a dimension of $1000 \mathrm{~m}$ (N-S axis) by $500 \mathrm{~m}(\mathrm{E}-\mathrm{W})$ axis. A detailed description of the site is given by [11]. 
The 50-ha KFDP was the best site to evaluate the spatial relationship between mycorrhiza status and trees species diversity because of its tree species richness. This plot has 329,026 trees belonging to 62 identified families. The area has been well mapped out into quadrats of $20 \mathrm{~m} \times 20 \mathrm{~m}$. All trees within each quadrat have been identified to the species level and data on the topography of the site is also available [11].

\subsection{Plot Layout}

100 quadrats of $20 \mathrm{~m} \times 20 \mathrm{~m}$ were selected at random within the plot as specific study sites. Selection was such that the different topography was represented. Care was also taken to ensure that quadrats with fewer or no trees were represented. Selection was facilitated by the use of existing topographic survey and tree maps of the area. Within the selected quadrats, five individuals representing each family of tree existing in it were sampled randomly.

\subsection{Field Collection of Roots}

Root samples were collected from randomly selected plants within the four habitat types in the study site. Fine roots were collected by tracing larger roots from the collar of tagged trees with the aid of a knife and trowel. Samples were washed free of debris and preserved in labeled vials containing 50\% ethanol.

Sampling was done four times a year. There was sampling during the dry season, the transition between dry and rainy season, during the rainy season and the transition period between the wet and the dry season.

\subsection{Evaluation of Root Samples}

This was carried out based on the method reported in [13]. Non-EM root samples and portions of EM root samples were rinsed properly with tap water to remove the ethanol. These were then cleared by immersing in $10 \%$ $\mathrm{KOH}$ for $48 \mathrm{~h}$. Roots were rinsed with tap water to remove the clearing solution, before staining in $0.05 \%$ trypan blue for 2 - 3 days. Stained roots were rinsed in tap water and hand sectioned with the aid of a razor blade into approximately $1 \mathrm{~cm}$ long pieces. Pieces were selected at random, placed on a glass slide and gently squashed under a cover slip followed by observation under a compound microscope. The usual basis for determining arbuscular mycorrhiza was the presence of characteristic internal hyphae and arbuscules while ectomycorrhiza was determined by the presence of a hyphal mantle on ultimate-order rootlets and hartig net on sections.

\subsection{Data Analysis}

Information on diversity of mycorrhizal associations collected would be compared with already existing data on plant species diversity of the study site to see whether there is any correlation. Data was analyzed using the Pearsons chi-square test to determine the effect of habitat type on mycorrhiza colonization, as well as to determine the influence of mycorrhiza in the maintenance of high tree species diversity.

\section{Results}

\subsection{Mycorrhiza Colonization}

The 781 individual trees sampled belonged to 51 families, 165 genera and 252 tree species. Of these, 248 species were mycorrhizal with only 4 being non mycorrhizal. Most of the trees $(92.06 \%)$ formed AM with just 3.97\% forming EM. The observations are summarized on Table 1 and Appendix.

Ten tree species formed EM which included; Angylocalyx oligophyllus Bak. (Fabaceae), Angylocalyx pynaertii (Fabaceae), Anthonotha fragrance (Fabaceae), Anthonotha sp. (Fabaceae), Baikiaea insignis Taub. (Fabaceae), Baphia capparidifolia Bak. (Fabaceae), Berlinia auriculata Benth. (Fabaceae), Calpocalyx dinklagei Harms. (Fabaceae), Dialium sp. (Fabaceae) and Gilbertiodendron demonstrans Baill. (Fabaceae). Dual associations of AM and EM were found in Hymenostegia afzelii Oliv., Uapaca staudtii Pax., Antidesma laciniatum Muell., Baphia laurifolia Baill., Leptonychia pallida K. Schum. and Soyauxia gabonensis Oliv. but only $H$. afzelii and U. staudtii harbored both AM and EM structures in the same root sample. Lasianthus batangensis $\mathrm{K}$. Schum., Trichoscypha preussii Engl. Hypodaphnis zenkeri Engl. and Memecylon zenkeri Gilg. did not harbor any mycorrhizal structures. All families formed mycorrhizal associations, with EsM associations being seemingly restricted to the Fabaceae (Appendix). 


\subsection{Effect of Habitat Type on Mycorrhiza Colonization}

Table 2 gives a summary of mycorrhiza colonization in the different habitats. Generally, mycorrhiza trees were found in all the four habitat types: low-drier (LD), hill slopes (HS), ridge top (RT) and wetland complexes (WC). Over $98 \%$ of the trees sampled in each habitat were mycorrhizal with most of them forming AM nonetheless; a few tree species showed some variability in their status and type of mycorrhiza formed (Table 3 ).

From the two way ANOVA test, habitat type had no significant effect $(\mathrm{P}=0.593)$ on mycorrhization. Pearson correlation test showed that there was no correlation $(\mathrm{P}=0.739)$ between abundance of mycorrhizal tree species per habitat type and tree diversity for the different habitat types.

From the data collected by [10] which gave distribution maps of individual tree species and the number of stem counts, we analyzed and observed that out of the ten tree species that formed EM, 3 of the tree species showed random distribution while 7 tree species were clumped in some habitat types (Table 4).

\section{Discussions}

Over $98.4 \%$ of the total number of tree species sampled formed mycorrhiza. This observation was consistent with those of [9] in which all 100 taxa studied were mycorrhizal. In an earlier study carried out by [14] in a different part of the korup national park, 56 tree species were investigated for mycorrhiza colonization and only one species; Warmekea memcyloides (Melastomataceae) was non mycorrhizal. Reference [15] also recorded a $100 \%$ mycorrhizal presence in their study.

Trees harboring AM structures far exceeded those forming EM. 232 tree species out of the 252 surveyed formed AM. This finding was quite similar to those of previous work carried out in this domain as compiled in [16] and [2]. The results from this study also confirmed the taxonomic dominance of AM tree species in the rain forests. All the four habitat types were glaringly dominated by AM trees both in species and in number of trees, except in the wetland complexes where the number of EM trees exceeded the number of AM trees (Table 5).

Table 1. Summary of the results obtained after sampling 781 individual trees for the presence of mycorrhiza structures.

\begin{tabular}{cccc}
\hline Mycotype & Number of individual trees & Number of tree species & \% of tree species \\
\hline AM & 709 & 232 & 92.06 \\
EM & 57 & 10 & 3.97 \\
Dual (AM and EM) & 8 & 6 & 2.38 \\
Non mycorrhizal & 7 & 4 & 1.59 \\
\hline
\end{tabular}

Table 2. Summary of mycorrhiza status and type in different habitat types in the 50-ha KFDP.

\begin{tabular}{|c|c|c|c|c|c|c|}
\hline Habitat type & $\begin{array}{l}\text { Total individual } \\
\text { trees sampled }\end{array}$ & $\begin{array}{c}\text { Total tree } \\
\text { species sampled }\end{array}$ & Mycotype & $\begin{array}{c}\text { Number of } \\
\text { individual trees }\end{array}$ & Tree species & $\%$ tree species \\
\hline \multirow{4}{*}{ Low-lying drier areas } & \multirow{4}{*}{268} & \multirow{4}{*}{147} & $\mathrm{AM}$ & 245 & 137 & 93.20 \\
\hline & & & EM & 19 & 7 & 4.76 \\
\hline & & & $\mathrm{AM}$ and $\mathrm{EM}$ & 2 & 1 & 0.68 \\
\hline & & & None & 2 & 2 & 1.36 \\
\hline \multirow{4}{*}{ Hill slopes and gullies } & \multirow{4}{*}{178} & \multirow{4}{*}{117} & $\mathrm{AM}$ & 160 & 108 & 92.31 \\
\hline & & & EM & 15 & 7 & 5.98 \\
\hline & & & $\mathrm{AM}$ and $\mathrm{EM}$ & 2 & 1 & 0.86 \\
\hline & & & None & 1 & 1 & 0.86 \\
\hline \multirow{4}{*}{ Ridge top } & \multirow{4}{*}{153} & \multirow{4}{*}{81} & $\mathrm{AM}$ & 142 & 76 & 93.83 \\
\hline & & & EM & 7 & 3 & 3.70 \\
\hline & & & $\mathrm{AM}$ and $\mathrm{EM}$ & 3 & 1 & 1.24 \\
\hline & & & None & 1 & 1 & 1.24 \\
\hline \multirow{4}{*}{ Wetland complexes } & \multirow{4}{*}{182} & \multirow{4}{*}{100} & $\mathrm{AM}$ & 162 & 90 & 90.00 \\
\hline & & & EM & 16 & 7 & 7.00 \\
\hline & & & $\mathrm{AM}$ and $\mathrm{EM}$ & 1 & 1 & 1.00 \\
\hline & & & None & 3 & 2 & 2.00 \\
\hline
\end{tabular}


Table 3. Inconsistency in mycorrhiza types of tree species in the different habitats of the 50-ha KFDP.

\begin{tabular}{|c|c|c|c|c|c|}
\hline Species & Family & Low-lying drier areas & Hill slopes and gullies & Ridge top & Wetland complexes \\
\hline Dactyladenia staudtii & Chrysobalanaceae & $\mathrm{AM}$ & $\mathrm{AM}$ & $\mathrm{X}$ & $\mathrm{X}$ \\
\hline Baphia laurifolia & Fabaceae & $\mathrm{AM}$ & EM & - & - \\
\hline Hymenostegia afzelii & Fabaceae & EM_AM & EM & - & EM \\
\hline Leptonychia pallida & Malvaceae & - & $\mathrm{AM}$ & EM & - \\
\hline Soyauxia gabonensis & Medusandraceae & $\mathrm{AM}$ & - & - & EM \\
\hline Uapaca staudtii & Phyllanthaceae & EM & EM_AM & EM, AM & EM \\
\hline Aulacocalyx jaminiflora & Rubiaceae & $\mathrm{AM}$ & - & $\mathrm{X}$ & - \\
\hline
\end{tabular}

Note: List of Abbreviations; $\mathrm{X}=$ Absence of mycorrhiza structures; EM AM = AM and EM structures on the same root; EM, AM = AM and EM structures on different root samples; $-=$ tree species were not sampled in the habitat.

Table 4. Distribution of EM tree species and stem count in the 50-ha KFDP.

\begin{tabular}{ccc}
\hline Distribution pattern & List of EM tree species & Stem count in study site \\
\hline Random & Angylocalyx pynaertii & 57 \\
& Anthonotha fragrans & 247 \\
Aggregated/clumped & Dialium sp. & 66 \\
& Angylocalyx oligopyllus & 5796 \\
& Calpocalyx dinklagei & 3066 \\
& Anthonotha sp. & 7 \\
& Baikaea insignis & 20 \\
& Baphia capparidifolia & 1767 \\
\hline
\end{tabular}

Table 5. Abundance of mycorrhizal trees in different habitat types in the 50-ha KFDP.

\begin{tabular}{cccccc}
\hline Habitat type & $\begin{array}{c}\text { Area per } \\
\text { habitat }\end{array}$ & $\begin{array}{c}\text { Abundance } \\
\text { of AM trees }\end{array}$ & $\begin{array}{c}\text { Abundance of } \\
\text { AM trees } \\
\text { per hectare }\end{array}$ & $\begin{array}{c}\text { Abundance } \\
\text { of EM trees }\end{array}$ & $\begin{array}{c}\text { Abundance } \\
\text { of EM trees } \\
\text { per hectare } \\
\text { diversity per quadrat } \\
\text { per habitat type }\end{array}$ \\
\hline Low-lying drier areas & 15.2 ha & 81602 & 5368.6 & 3334 & 219.3 \\
Hill slopes and gullies & 9.5 ha & 325581 & 3429.6 & 3194 & 336.2 \\
Ridge top & 9.0 ha & 31461 & 3495.7 & 1976 & 219.6 \\
Wetland complexes & $16 . h a$ & 46950 & 2880.4 & 5609 & 344.1 \\
\hline
\end{tabular}

This observation was unlike that of [6] in which endomycorrhizal species dominated in number of species but not in volume.

Ten tree species formed EM and all belonged to the Fabaceae. Reference [8] had earlier shown that only about 3\% of tree species do form EM. Similarly [9] found that 26 out of the 100 tree species sampled formed EM. Reference [14] recorded 20 ectomycorrhizal tree species out $\mathrm{f}$ the 56 sampled. This was certainly because they set out to sample some species of leguminosae and members of this family had been reported to be ectomycorrhizal [2] [16].

Six tree species formed dual mycorrhizal associations, but just two species; Hymenostegia afzelii and Uapaca staudtii harbored both EM and AM structures in the same root sample. Reference [17] also found dual mycorrhiza associations in the korup national park. U. staudtii was also reported by [16] as being dual mycorrhizal.

Dactyladenia staudtii Engl. was non mycorrhizal in the wetland complexes but formed AM in the hill slopes and gullies. This was probably because the very wet nature of the wetland complexes affected the availability of inoculum as well as the plants' ability to form mycorrhizas. Aulacocalyx jamiiflora was AM in low-lying drier areas but non mycorrhizal in the ridge top. The change in altitude might have been the reason for this observation. Reference [2] proposed that inconsistency in mycorrhizal relationships could be attributed to habitat factors that result to adaptation to stressful conditions such as waterlogged soils.

Hypodaphnis zenkeri was non mycorrhizal in this study but had been reported to form AM by [14]. This dif- 
ference in observation was probably because this plant was only sampled in the wetland complexes in this study. It may have adapted the non mycorrhizal status to enable it survive the waterlogged nature of its surrounding.

\section{Conclusion}

Since habitat type did not significantly influence mycorrhizal colonization, it was concluded that mycorrhiza could not be seen as a biological tool for driving species diversity in the study site. Most of the trees sampled formed arbuscular mycorrhiza while ectomycorrhiza formation seemed to be restricted to the fabaceae.

\section{Acknowledgements}

We would like to acknowledge the field assistants at the Korup Forest Dynamics Plot (KFDP) and Conservator of Korup National Park Mundemba. Creation of the Korup Forest Dynamics Plot was made possible through the generous support of the National Institutes of Health award U01 TW03004 under the NIH-NSF-USDA funded International Cooperative Biodiversity Groups program, with additional financial support from the US Agency for International Development's Central Africa Regional Program for the Environment, and the Smithsonian Tropical Research Institute. This work was financed by a University of Buea Research Grant number 2008/A25. We also thank the anonymous reviewers for their contributions towards the improvement of this manuscript.

\section{References}

[1] Bechem, E.E.T. and Alexander, I.J. (2012) Mycorrhizal Status of Gnetum spp. in Cameroon: Evaluating Diversity with a View to Ameliorating Domestication Efforts. Mycorrhiza, 22, 99-108. http://dx.doi.org/10.1007/s00572-011-0384-0

[2] Brundrett, M.C. (2009) Mycorrhizal Associations and Other Means of Nutrition of Vascular Plants: Understanding the Global Diversity of Host Plants by Resolving Conflicting Information and Developing Reliable Means of Diagnosis. Plant Soil, 320, 37-77. http://dx.doi.org/10.1007/s11104-008-9877-9

[3] Alexander, I.J. (1989) Mycorrhizas in Tropical Forests. In: Proctor, J., Ed., Mineral Nutritients in Tropical Forest and Savanna Ecosystems, Blackwell Scientific Publications, Oxford, 169-188.

[4] Alexander, I.J. (1989) Systematics and Ecology of Ectomycorrhizal Legumes. In: Stirton, C.H. and Zaruccchi, J.L., Eds., Advances in Legume Biology, Monograph of Systematic Botany (Vol. 29), Missouri Botanical Garden, 607-624.

[5] St. John, T.V. (1980) A Survey of Micorrhizal Infection in an Amazonian Rain Forest. Acta Amazonica, 10, $527-533$.

[6] Högberg, P. (1982) Mycorrhizal Associations in Some Woodland and Forest Trees and Shrubs in Tanzania. New Phytologist, 92, 407-415. http://dx.doi.org/10.1111/j.1469-8137.1982.tb03398.x

[7] Buyck, B., Thoen, D. and Watling, R. (1996) Ectomycorrhiza Fungi of the Guinea-Congo Region. Proceedings of the Royal Society of Edinburgh, 104B, 313-333.

[8] Smith, S. and Read, D. (2008) Mycorrhizal Symbiosis. 3rd Edition, Academic Press, San Diego.

[9] Onguene, N.A. and Kuyper, T.W. (2001) Mycorrhizal Associations in the Rain Forest of South Cameroon. Forest Ecology and Management, 140, 277-287. http://dx.doi.org/10.1016/S0378-1127(00)00322-4

[10] Thomas, D.W., Kenfack, D., Chuyong, G.B., Sainge, N.M., Losos, E.C., Condi,t R.S. and Songwe, N.C. (2003) Tree Species of South Western Cameroon: Tree Distriburtion Maps, Diameter Tables and Species Documentation of the 50-Hectare Korup Forest Dynamics Plot. Centre for Tropical Forest Science of the Smithsonian Tropical Research Institute and Bioresources Development and Conservation Programme-Cameroon. Washington D.C.

[11] Chuyong, G.B., Condit, R., Kenfack, D., Losos, E.C., Sainge, N.M., Songwe, N.C. and Thomas, T.W. (2004) Korup Forest Dynamic Plot, Cameroon. In: Losos and Leigh, Eds., Tropical Forest Diversity and Dynamism. Findings from a Large-Scale Plot Network, The University of Chicago Press, 11.

[12] Kenfack, D., Thomas, D.W., Chuyong, G.B. and Condit, R. (2007) Rarity and Abundance in a Diverse African Forest. Biodiversity Conservation, 16, 2045-2074. http://dx.doi.org/10.1007/s10531-006-9065-2

[13] Brundett, M.C., Piché, Y. and Peterson, R.L. (1984) A New Method for Observing the Morphology of Vesicular-Arbuscular mycorrhizae. Canadian Journal of Botany, 62, 2128-2134. http://dx.doi.org/10.1139/b84-290

[14] Newbery, D.M., Alexander, I.J., Thomas, D.W. and Gartland, J.S. (1988) Ectomycorrhizal Rain Forest Legumes and Soil Phosphorus in Korup National Park, Cameroon. New Phytologist, 109, 433-450. http://dx.doi.org/10.1111/j.1469-8137.1988.tb03719.x

[15] Ifeoma, A. F. and Ene-Obong, E.E. (2010) Studies on Mycorrhizae Development and Anatomical Confirmation of Mycorrhizae Formed on Pinus caribaea Mor. var. Hondurensis Barr. And Golf. Seedlings. African Journal of Microbiology Research, 4, 367-379. 
[16] Wang, B. and Qui, Y.-L. (2006) Phylogenetic Distribution and Evolution of Mycorrhizas in Land Plants. Mycorrhiza, 16, 299-363. http://dx.doi.org/10.1007/s00572-005-0033-6

[17] Moyersoen, B., Fitter, A.H. and Alexander, I.J. (1998) Spatial Distribution of Ectomycorrhizas and Arbuscular Mycorrhizas in Korup National Park Rain Forest, Cameroon, in Relation to Edaphic Parameters. New Phytologist, 139, 311-320. http://dx.doi.org/10.1046/j.1469-8137.1998.00190.x 
Appendix. Mycorrhizal status and type, of tree species collected at random from four habitat types in the 50-ha KFDP, Korup National Park, Cameroon; including tree species of economic and conservative values.

\begin{tabular}{|c|c|c|c|c|c|c|c|c|c|c|c|}
\hline \multirow{2}{*}{ SN } & \multirow{2}{*}{ FAMILY } & \multirow{2}{*}{ SPECIES } & \multicolumn{2}{|c|}{ LD } & \multicolumn{2}{|c|}{ HS } & \multicolumn{2}{|c|}{ RT } & \multicolumn{2}{|c|}{ WC } & \multirow[t]{2}{*}{$\mathrm{E} / \mathrm{C}$} \\
\hline & & & $\mathbf{A M}$ & EM & $\mathbf{A M}$ & EM & $\mathbf{A M}$ & $\mathbf{E M}$ & $\mathbf{A M}$ & $\mathbf{E M}$ & \\
\hline 1 & \multirow[t]{6}{*}{ Acanthaceae } & Asystasia macrophylla & + & - & & & & & & & \\
\hline 2 & & Dasylepis blackii & + & - & & & + & - & + & - & \\
\hline 3 & & Scottelia klaineana & & & + & - & & & & & \\
\hline 4 & & Trichoscypha acuminata & & & & & + & - & + & - & \\
\hline 5 & & Trichoscypha klainei & + & - & & & & & & & \\
\hline 6 & & Trichoscypha patens & + & - & + & - & + & - & & & $\mathrm{EF}$ \\
\hline 7 & \multirow{9}{*}{ Anacardiaceae } & Trichoscypha preussii & - & - & & & & & & & \\
\hline 8 & & Trichoscypha sp. & + & - & + & - & & & & & \\
\hline 9 & & Trichoscypha sp. 3 & & & + & - & & & & & \\
\hline 10 & & Annickia chlorantha & + & - & & & & & & & $\mathrm{M}, \mathrm{ND}, \mathrm{LT}$ \\
\hline 11 & & Isolana campanulata & + & - & + & - & & & & & \\
\hline 12 & & Isolana sp. & & & + & - & & & & & \\
\hline 13 & & Pachypodanthium sp. & & & & & & & + & - & \\
\hline 14 & & Piptostigma oyemense & + & - & & & + & - & + & - & \\
\hline 15 & & Polyceratocarpus parviflorus & + & - & & & + & - & + & - & \\
\hline 16 & \multirow{12}{*}{ Annonaceae } & Uvariastrum pynaertii & & & + & - & & & + & - & \\
\hline 17 & & Uvariodendron sp. & + & - & + & - & + & - & + & - & \\
\hline 18 & & Uvariopsis bakeriana & & & + & - & & & & & $\mathrm{R}$ \\
\hline 19 & & Uvariopsis congolana & & & & & + & - & & & \\
\hline 20 & & Uvariopsis korupensis & & & & & & & + & - & $\mathrm{R}$ \\
\hline 21 & & Xylopia acutiflora & + & - & & & & & + & - & \\
\hline 22 & & Xylopia aethiopica & & & & & + & - & & & $\mathrm{M}, \mathrm{LT}, \mathrm{EF}$ \\
\hline 23 & & Xylopia sp. 2 & & & & & + & - & & & \\
\hline 24 & & Alstonia boonei & & & + & - & + & - & + & - & $\mathrm{M}, \mathrm{CT}$ \\
\hline 25 & & Funtumia elastica & + & - & & & & & & & \\
\hline 26 & & Hunteria umbellata & + & - & + & - & + & - & & & \\
\hline 27 & & Pleiocarpa rostrata & + & - & + & - & + & - & & & \\
\hline 28 & \multirow[t]{5}{*}{ Apocynaceae } & Rauvolfia caffra & + & - & + & - & + & - & + & - & \\
\hline 29 & & Rauvolfia mannii & + & - & & & & & + & - & \\
\hline 30 & & Rauvolfia vomitoria & + & - & & & + & - & & & M \\
\hline 31 & & Tabernaemontana brachyantha & + & - & & & & & + & - & M \\
\hline 32 & & Tabernaemontana crassa & + & - & + & - & & & & & M \\
\hline 33 & Asteraceae & Vernonia frondosa & + & - & & & & & + & - & \\
\hline 34 & Bignoniaceae & Spathodea campanulata & & & + & - & & & & & \\
\hline 35 & \multirow{3}{*}{ Burseraceae } & Dacryodes klaineana & & & & & & & + & - & 36 \\
\hline 36 & & Santiria balsamifera & + & - & & & & & & & \\
\hline 37 & & Salacia lehmbachii & + & - & + & - & + & - & + & - & \\
\hline 38 & \multirow[t]{3}{*}{ Celastraceae } & Salacia loloensis & + & - & + & - & + & - & + & - & \\
\hline 39 & & Salacia sp. nov. & + & - & + & - & + & - & & & $\mathrm{R}$ \\
\hline 40 & & Chrysobalanus icaco & + & - & + & - & & & & & \\
\hline 41 & \multirow{3}{*}{ Chrysobalanaceae } & Dactyladenia staudtii & & & + & - & & & - & - & \\
\hline 42 & & Magnistipula glaberrima & + & - & + & - & & & & & \\
\hline 43 & & Dactyladenia pallescens & & & & & & & & & \\
\hline 44 & \multirow{2}{*}{ Clusiaceae } & Endodesmia calophylloides & + & - & & & + & - & + & - & \\
\hline 45 & & Garcinia conrauana & + & - & & & & & & & \\
\hline
\end{tabular}




\section{Continued}

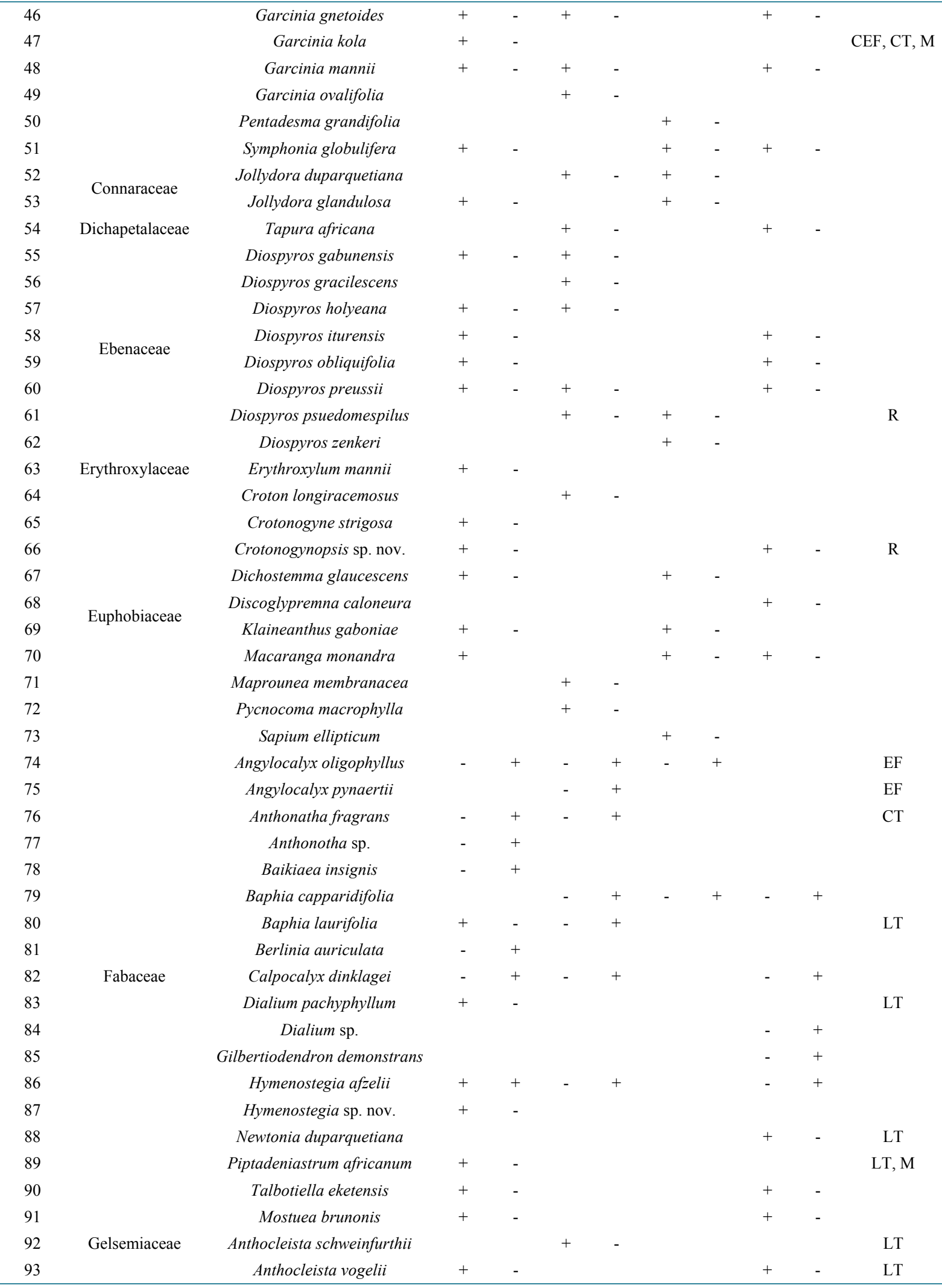




\section{Continued}

\begin{tabular}{|c|c|c|c|c|c|c|c|c|c|c|c|}
\hline 94 & \multirow{2}{*}{ Icacinaceae } & Lasianthera africana & + & - & + & - & + & - & + & - & LT, EL \\
\hline 95 & & Leptaulus daphnoides & + & - & & & + & - & & & \\
\hline 96 & \multirow{3}{*}{ Irvingiaceae } & Desbordesia glaucescens & + & - & & & & & & & LT, ES \\
\hline 97 & & Irvingia gabonensis & + & - & & & & & + & - & CES \\
\hline 98 & & Klainedoxa trillesii & & & + & - & & & & & \\
\hline 99 & Lamiaceae & Vitex grandifolia & + & - & & & + & - & & & \\
\hline 100 & \multirow{6}{*}{ Lauraceae } & Beilschmiedia jacques-felixii & & & & & & & + & - & \\
\hline 101 & & Beilschmiedia sp. 2 & & & & & + & - & & & \\
\hline 102 & & Beilschmiedia sp. 3 & & & & & & & & & \\
\hline 103 & & Hypodaphnis zenkeri & & & & & & & - & - & LT \\
\hline 104 & & Napoleonaea talbotii & + & - & + & - & & & & & \\
\hline 105 & & Oubanguia alata & + & - & + & - & & & + & - & ES \\
\hline 106 & \multirow[t]{3}{*}{ Lecythidaceae } & Oubanguia laurifolia & & & & & & & + & - & \\
\hline 107 & & Rhaptopetalum sp. nov. & & & & & + & - & + & - & $\mathrm{R}$ \\
\hline 108 & & Scytopetalum klaineana & & & & & & & + & - & \\
\hline 109 & \multirow[t]{19}{*}{ Lepidobotryaceae } & Lepidobotrys staudtii & & & & & + & - & & & \\
\hline 110 & & Cola acuminata & & & + & - & & & & & CES \\
\hline 111 & & Cola cauliflora & + & - & & & & & + & - & \\
\hline 112 & & Cola chlamydantha & + & - & & & & & & & \\
\hline 113 & & Cola digitata & + & - & & & & & & & \\
\hline 114 & & Cola lepidota & + & - & & & & & & & $\mathrm{CEF}$ \\
\hline 115 & & Cola praeacuta & + & - & + & - & + & - & + & - & $\mathrm{R}$ \\
\hline 116 & & Cola rostrata & + & - & + & - & & & & & \\
\hline 117 & & Cola semecarpophylla & + & - & + & - & & & & & \\
\hline 118 & & Cola sp. nov. 2 & + & - & + & - & + & - & + & - & \\
\hline 119 & & Cola sp. nov. 3 & + & - & & & & & + & - & $\mathrm{R}$ \\
\hline 120 & & Cola suboppositifolia & & & + & - & + & - & + & - & $\mathrm{R}$ \\
\hline 121 & & Cola verticillata & & & & & & & + & - & $\mathrm{CEF}$ \\
\hline 122 & & Leptonychia echinocarpa & + & - & & & & & + & - & \\
\hline 123 & & Leptonychia pallida & & & + & - & - & + & & & \\
\hline 124 & & Microcos coriacea & & & & & & & + & - & \\
\hline 125 & & Scaphopetalum blackii & + & - & & & & & + & - & \\
\hline 126 & & Sterculia oblonga & & & + & - & & & & & $\mathrm{CT}$ \\
\hline 127 & & Sterculia tragacantha & & & + & - & & & & & $\mathrm{CT}$ \\
\hline 128 & Medusandraceae & Soyauxia talbotii & + & - & & & & & - & + & $\mathrm{R}$ \\
\hline 129 & \multirow[t]{2}{*}{ Melastomataceae } & Warneckea membranifolia & + & - & + & - & & & + & - & \\
\hline 130 & & Carapa parvifolia & + & - & & & & & + & - & \\
\hline 131 & \multirow{3}{*}{ Meliaceae } & Guarea thompsonii & & & + & - & & & & & $\mathrm{CT}$ \\
\hline 132 & & Trichilia sp. & + & - & & & & & & & \\
\hline 133 & & Turraeanthus mannii & + & - & & & & & & & $\mathrm{R}$ \\
\hline 134 & Melianthaceae & Bersama sp. & & & & & + & - & + & - & \\
\hline 135 & \multirow{2}{*}{ Memecylaceae } & Memecylon lateriflorum & + & - & & & & & + & - & \\
\hline 136 & & Memecylon zenkeri & & & - & - & & & & & \\
\hline 137 & Monimiaceae & Glossocalyx brevipes & + & - & & & & & + & - & \\
\hline 138 & \multirow{2}{*}{ Myristicaceae } & Coelocaryon preussii & & & & & & & + & - & $\mathrm{CT}, \mathrm{EF}$ \\
\hline 139 & & Pycnanthus angolensis & + & - & + & - & & & & & $\mathrm{CT}, \mathrm{M}$ \\
\hline 140 & \multirow{2}{*}{ Myrtaceae } & Eugenia fernandopoana & + & - & & & & & & & $\mathrm{R}$ \\
\hline 141 & & Eugenia talbotii & & & + & - & & & & & $\mathrm{R}$ \\
\hline
\end{tabular}




\section{Continued}

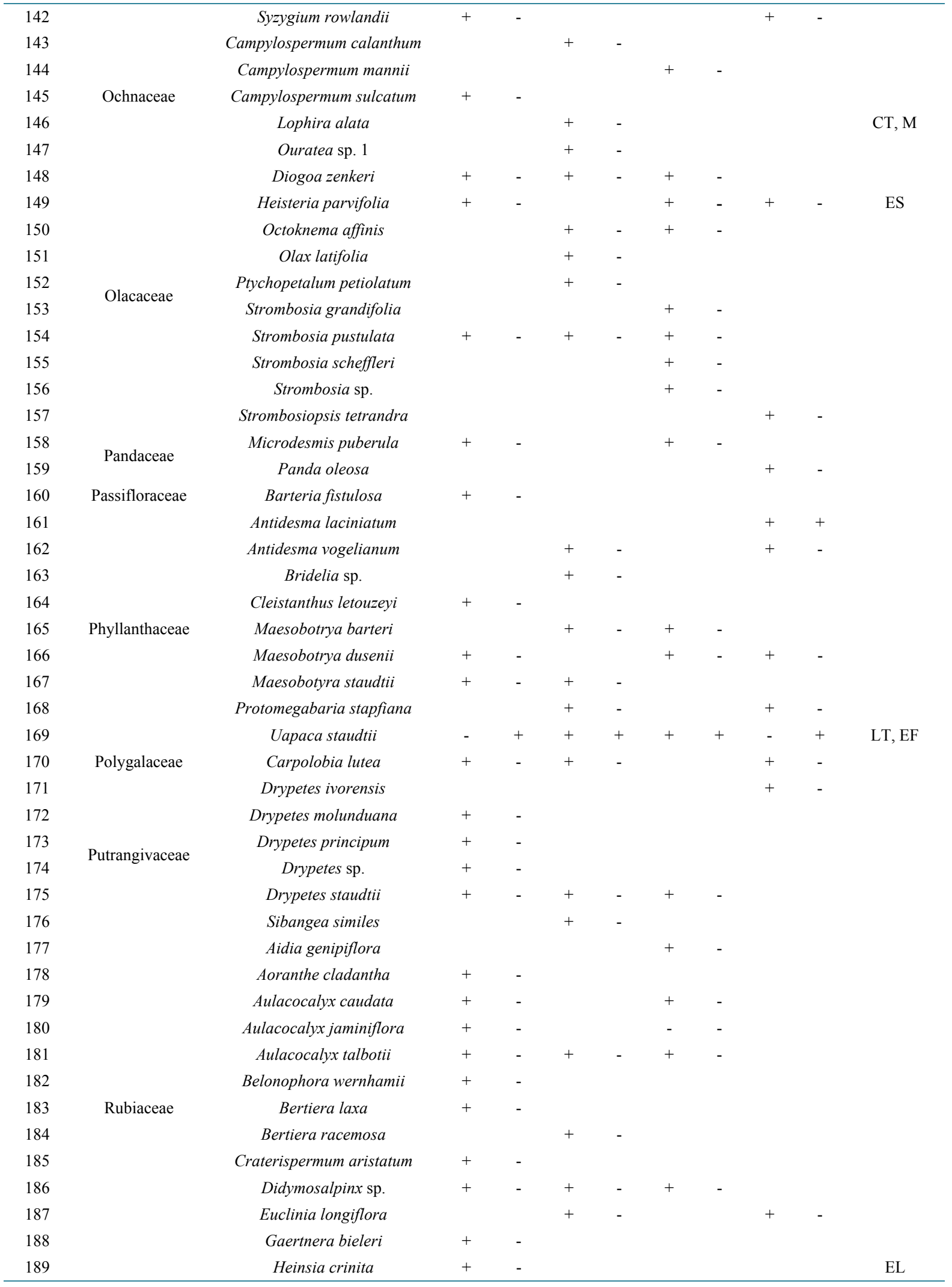




\section{Continued}

\begin{tabular}{|c|c|c|c|c|c|c|c|c|c|c|c|}
\hline 190 & & Ixora hippoperifera & & & + & - & + & - & + & - & \\
\hline 191 & & Ixora nematopoda & + & - & + & - & & & & & \\
\hline 192 & & Lasianthus batangensis & - & - & & & & & & & \\
\hline 193 & & Massularia acuminata & + & - & + & - & + & - & + & - & \\
\hline 194 & & Oxyanthus laxiflorus & + & - & + & - & + & - & & & \\
\hline 195 & & Pauridantha afzelii & & & + & - & + & - & + & - & \\
\hline 196 & & Pauridiantha floribunda & & & & & & & + & - & LD \\
\hline 197 & & Pausinystalia macroceras & & & + & - & + & - & + & - & M \\
\hline 198 & & Pavetta sp. 1 & + & - & & & & & + & - & \\
\hline 199 & & Petitiocodon parviflorum & + & - & + & - & & & & & \\
\hline 200 & & Polysphaeria macrophylla & + & - & + & - & & & & & \\
\hline 201 & & Psychotria dorotheae & + & - & + & - & + & - & + & - & \\
\hline 202 & & Psychtria sp. 8 & & & & & & & + & - & $\mathrm{R}$ \\
\hline 203 & & Rothmannia hispida & + & - & & & & & & & \\
\hline 204 & & Rothmannia talbotii & & & + & - & & & & & \\
\hline 205 & & Rubiaceae sp. RUBB & & & & & + & - & & & \\
\hline 206 & & Rubiaceae sp. RUBS & & & & & & & + & - & \\
\hline 207 & & Schumanniophyton magnificum & & & & & & & + & - & M \\
\hline 208 & & Sericanthe auriculata & & & + & - & & & & & \\
\hline 209 & & Stipularia africana & & & & & & & + & - & \\
\hline 210 & & Tarenna lasiorachis & + & - & & & & & & & \\
\hline 211 & & Tricalysia achoundongiana & + & - & & & & & & & $\mathrm{R}$ \\
\hline 212 & & Dracaena bicolor & + & - & + & - & & & + & - & \\
\hline 213 & Ruscaceae & Dracaena laxissima & + & - & & & & & + & - & \\
\hline 214 & & Dracaena sp. & + & - & & & & & & & \\
\hline 215 & & Araliopsis soyauxii & + & - & & & & & & & M \\
\hline 216 & Rutaceae & Oricia lecomteana & + & - & + & - & & & & & \\
\hline 217 & & Zanthoxylum gilletii & + & - & & & & & & & \\
\hline 218 & & Caloncoba gluaca & & & + & - & & & & & \\
\hline 219 & & Casearia barteri & & & & & + & - & & & \\
\hline 220 & Salicaceae & Homalium letestui & & & & & & & + & - & \\
\hline 221 & & Homalium longistylum & + & - & + & - & + & - & & & \\
\hline 222 & & Phyllobotryon spathulatum & & & & & + & - & & & \\
\hline 223 & & Chrysanthus sp. 2 & + & - & + & - & & & & & \\
\hline 224 & & Chrysanthus sp. 3 & & & + & - & & & & & \\
\hline 225 & & Chrysanthus talbotii & & & & & & & + & - & $\mathrm{EF}$ \\
\hline 226 & Sanindaceae & Deinbolia maxima & & & & & & & + & - & \\
\hline 227 & & Deinbollia pychnophylla & + & - & & & & & & & \\
\hline 228 & & Eriocoelum sp. & & & & & & & + & - & \\
\hline 229 & & Laccodiscus ferrugineus & & & + & - & + & - & & & \\
\hline 230 & & Placodiscus sp. & + & - & + & - & & & & & \\
\hline 231 & & Aporrhiza sp. & & & + & - & & & & & \\
\hline 232 & & Chrysophyllum delevoyi & & & & & & & + & - & $\mathrm{EF}$ \\
\hline 233 & & Chrysophyllum sp. nov. & & & + & - & & & & & \\
\hline 234 & Sapotaceae & Englerophytum sp. nov. & & & + & - & + & - & & & $\mathrm{EF}$ \\
\hline 235 & & Lecomtedoxa klaineana & + & - & & & & & & & LT \\
\hline 236 & & Synsepallum stipulatum & & & + & - & & & & & \\
\hline 237 & & Zeyherella letestui & & & + & - & & & & & \\
\hline
\end{tabular}




\section{Continued}

\begin{tabular}{|c|c|c|c|c|c|c|c|c|c|c|c|}
\hline 238 & Thymelaeaceae & Dicranolepis disticha & + & - & & & & & & & \\
\hline 239 & Urticaceae & Musanga cecropioides & + & - & + & - & + & - & + & - & M, LT \\
\hline 240 & & Allexis cauliflora & & & + & - & & & & & \\
\hline 241 & & Rinorea dentata & + & - & + & - & + & - & + & - & \\
\hline 242 & & Rinorea gabunensis & + & - & + & - & + & - & & & \\
\hline 243 & & Rinorea kamerunensis & + & - & + & - & & & + & - & \\
\hline 244 & & Rinorea leiophylla & + & - & & & & & + & - & \\
\hline 245 & Violaceae & Rinorea lepidobotrys & + & - & & & & & + & - & \\
\hline 246 & & Rinorea oblongifolia & + & - & + & - & + & - & & & \\
\hline 247 & & Rinorea sp. 2 & + & - & + & - & + & - & & & \\
\hline 248 & & Rinorea subintegrifolia & + & - & + & - & + & - & + & - & \\
\hline 249 & & Rinorea thomasii & + & - & & & & & & & $\mathrm{R}$ \\
\hline 250 & & Rinorea woermanniana & + & - & & & + & - & + & - & \\
\hline 251 & Vochysiaceae & Erismadelphus exsul & & & + & - & + & - & + & - & \\
\hline 252 & Unidentified & Unidentified UNID & + & - & & & + & - & & & \\
\hline
\end{tabular}

Note List of Abbreviations: +: Presence of mycorrhiza; -: Absence of mycorrhiza; AM = Arbuscular mycorrhiza; EM = Ectomycorrhiza; LD = Low-Drier areas; HS = Hill Slope; RT = Ridge Top; $\mathrm{WC}=$ Wetland Complex; $\mathrm{ALL}=\mathrm{LD}, \mathrm{HS}, \mathrm{RT}$, WC; $\mathrm{LT}=\mathrm{Local}$ timber; ND = Natural dye; R = Rare species (IUCN); $\mathrm{M}=$ Medicinal value; $\mathrm{EF}=$ Edible fruits; $\mathrm{ES}=$ Edible seeds; $\mathrm{CES}=$ commercially edible seeds; $\mathrm{EL}=\mathrm{Edible}$ leaves; $\mathrm{E} / \mathrm{C}=$ Economic/Conservative status; $\mathrm{CEF}=$ Commercially edible fruits; $\mathrm{CT}=$ Commercial timber; Codes refer to species not identified in the families. 